\title{
The Effects of Dietary Gracilaria Corticata (Marine Macroalgae, Rhodophyta) Extraction on Growth Performance, Antioxidant Defence, Plasma and Mucosal Immune Components and Immune-related Gene Expressions in Goldfish, Carassius Auratus
}

\section{Research Article}

Keywords:

Posted Date: October 5th, 2022

DOI: https://doi.org/10.21203/rs.3.rs-1234382/v2

License: (c) (i) This work is licensed under a Creative Commons Attribution 4.0 International License. Read Full License

\section{EDITORIAL NOTE:}

This preprint was withdrawn by Research Square on 5 October 2022 due to concerns with authorship. These issues are described on the PubPeer platform. 


\section{Abstract}

Research Square has withdrawn this preprint due to authorship disputes.

\section{Full Text}

The authors have withdrawn this preprint from Research Square. 